\title{
Correction to: Just War Theory AND Literary STUDIES
}

\section{Correction to:}

T. Hawkins, A. Kim, Just War Theory and Literary Studies, American Literature Readings in the 21st Century, https://doi.org/10.1007/978-3-030-79863-5

The book was inadvertently published with the notes to the editorial team in the online abstracts of "Introduction" and "Right Intention". This has been updated in the book.

The updated version of the chapters can be found at https://doi.org/10.1007/978-3-030-79863-5_1 https://doi.org/10.1007/978-3-030-79863-5_2

(C) The Author(s), under exclusive license to Springer Nature Switzerland AG 2021

T. Hawkins, A. Kim, Just War Theory and Literary Studies, American Literature Readings in the 21 st Century, https://doi.org/10.1007/978-3-030-79863-5_9 